\title{
PEROLEHAN TANAH \\ DALAM PENGADAAN TANAH BERSKALA KECIL
}

\author{
Urip Santoso \\ (D osen Tetap Pada F akultas H u kum U niversitas A irlangga, JIn. D armawangsa \\ D alam selatan Surabaya)
}

\begin{abstract}
A bstract:
Government is a side or party that needs land in terms of trivial scale of land provision. The way of land acquisition in trivial scale must pass through the way of referential settlement release by the land owner. It is not allowed to have it by purcahsing and saling and also exchanging. The later way of land acquisition cannot be done due tp in adequacy of term of material of purcahsing and saling as well as exchanging.
\end{abstract}

\section{Key Words:}

Pengadaan tanah, berskala kecil, jual beli, tukar-menukar, dan pelepasan hak atastanah.

\section{Pendahuluan}

Pengadaan tanah bagi pelaksanaan pembangunan untuk kepentingan umum diatur dalam Peraturan Presiden No. 36 Tahun 2005 tentang Pengadaan Tanah Bagi Pelaksanaan Pembangunan untuk Kepentingan Umum. Peraturan Presiden No. 36 Tahun 2005 menyatakan tidak berlaku lagi Keputusan Presiden No. 55 Tahun 1993 tentang Pengadaan Tanah Bagi Pelaksanaan Pembangunan untuk Kepentingan Umum. Peraturan Presiden No. 36 Tahun 2005 diubah oleh Peraturan Presiden No. 65 Tahun 2006 tentang Perubahan atas Peraturan Presiden Nomor 36 Tahun 2005 tentang Pengadaan Tanah bagi Pelaksanaan Pembangunan Untuk Kepentingan Umum. Peraturan Presiden No. 36 Tahun 2005 dilaksanakan oleh Peraturan Kepala Badan Pertanahan Nasional Republik Indonesia No. 3 Tahun 2007 tentang Ketentuan Pelaksanaan Peraturan Presiden Nomor 36 Tahun 2005 tentang Pengadaan Tanah bagi Pelaksanaan Pembangunan untuk Kepentingan Umum Sebagaimana telah diubah dengan Peraturan Presiden Nomor 65 
UripSantoso

Tahun 2006 tentang Perubahan Atas Peraturan Presiden Nomor 36 Tahun 2005 tentang Pengadaan Tanah bagi Pelaksanaan Pembangunan untuk Kepentingan Umum. Peraturan Kepala Badan Pertanahan Nasional Republik Indonesia No. 3 Tahun 2007 menyatakan tidak berlaku lagi Peraturan Menteri Negara Agraria/ Kepala Badan Pertanahan Nasional No. 1 Tahun 1994 tentang Ketentuan Pelaksanaan Keputusan Presiden Nomor 55 Tahun 1993 tentang Pengadaan Tanah bagi Pelaksanaan Pembangunan Untuk Kepentingan U mum.

Pengadaan tanah bagi pelaksanaan pembangunan untuk kepentingan umum dalam Peraturan Presiden No. 36 Tahun 2005 dibagi menjadi 2 (dua) macam, yaitu: Pertama Pengadaan tanah untuk kepentingan umum yaitu pengadaan tanah bagi pelaksanaan pembangunan untuk kepentingan umum yang luas tanah yang diperlukan lebih dari 1 (satu) hektar disebut pengadaan tanah untuk kepentingan umum. Kedua, pengadaan tanah berskala kecil yaitu pengadaan tanah bagi pelaksanaan pembangunan untuk kepentingan umum yang luas tanah yang diperlukan tidak lebih dari 1 (satu) hektar disebut pengadaan tanah berskala kecil.

Semula, pengadaan tanah berskala kecil diatur dalam Pasal 23 Keputusan Presiden No. 55 Tahun 1993, yaitu: “Pelaksanaan pembangunan untuk kepentingan umum yang memerlukan tanah yang luasnya tidak lebih dari 1 (satu) hektar, dapat dilakukan langsung oleh instansi Pemerintah yang memerlukan tanah dengan para pemegang hak atas tanah, dengan cara jual beli, atau tukar menukar, atau cara lain yang disepakati oleh kedua belah pihak". Pasal 23 Keputusan Presiden No. 55 Tahun 1993 dilaksanakan oleh Pasal 41 Peraturan Menteri Negara Agraria/Kepala Badan Pertanahan Nasional No. 1 Tahun 1994, yaitu : “A pabila luas tanah yang diperlukan luasnya tidak lebih dari 1 (satu) hektar, setelah menerima persetujuan penetapan lokasi pembangunan untuk kepentingan umum sebagaimana dimaksud dalam Pasal 7 ayat (3), instansi Pemerintah yang memerlukan tanah dapat melaksanakan pengadaan tanah tersebut secara langsung dengan pemegang hak atas tanah dan pemilik bangunan, tanaman, dan/ atau benda-benda lain yang berkaitan dengan tanah yang bersangkutan atas dasar musyawarah". 
Perdehan Tanah

Keputusan Presiden No. 55 Tahun 1993 dinyatakan tidak berlaku lagi oleh Peraturan Presiden No. 36 Tahun 2005. Secara khusus dalam Pasal 20 Peraturan Presiden No. 36 Tahun 2005 diatur ketentuan pengadaan tanah berkala kecil, yaitu: "Pelaksanaan pembangunan untuk kepentingan umum yang memerlukan tanah yang luasnya tidak lebih dari 1 (satu) hektar, dapat dilakukan langsung oleh instansi Pemerintah yang memerlukan tanah dengan para pemegang hak atas tanah, dengan cara jual beli, atau tukar menukar, atau cara lain yang disepakati kedua belah pihak". Rumusan ketentuan pengadaan tanah berkala kecil dalam Pasal 20 Peraturan Presiden No. 36 Tahun 2005 sama dengan rumusan ketentuan pengadaan tanah berskala kecil dalam Pasal 23 Keputusan Presiden No. 55 Tahun 1993. Rumusan Pasal 20 Peraturan Presiden No. 36 Tahun 2005 menyalin rumusan Pasal 23 Keputusan Presiden No. 55 Tahun 1993.

Pasal 20 Peraturan Presiden No. 36 Tahun 2005 dilaksanakan oleh Pasal 54 Peraturan Kepala Badan Pertanahan Nasional Republik Indonesia No. 3 Tahun 2007, yang mengatur ketentuan pengadaan tanah berskala kecil, yaitu: "Pengadaan tanah bagi pelaksanaan pembangunan untuk kepentingan umum yang luasnya tidak lebih dari 1 (satu) hektar, dilaksanakan secara langsung melalui jual beli, tukar menukar, atau cara lain yang disepakati para pihak tanpa bantuan Panitia Pengadaan Tanah Kabupaten/ Kota atau dengan bantuan Panitia Pengadaan Tanah Kabupaten/ Kota".

Saat ini pengadaan tanah berkala kecil diatur dalam Pasal 20 Peraturan Presiden No. 36 Tahun 2005, yang dilaksanakan oleh Pasal 54 sampai dengan Pasal 60 Peraturan Kepala Badan Pertanahan Nasional Republik Indonesia No. 3 Tahun 2007. Pasal 20 Peraturan Presiden No. 36 Tahun 2005 dan Pasal 54 Peraturan Kepala Badan Pertanahan Nasional Republik Indonesia No. 3 Tahun 2007 menyebutkan 3 (tiga) cara perolehan tanah dalam pengadaan tanah berskala kecil, yaitu jual beli, tukar menukar, atau cara lain yang disepakati oleh kedua belah pihak. Namun demikian, dalam Pasal 55 sampai dengan Pasal 59 Peraturan Kepala Badan Pertanahan Nasional Republik Indonesia No. 3 Tahun 2007 tidak menyebut lagi tentang jual beli atau tukar menukar, tetapi menjabarkan cara perolehan tanah 
UripSantoso

dalam pengadaan tanah berskala kecil melalui pelepasan hak atas tanah.

Pihak yang memerlukan tanah dalam pengadaan tanah berskala kecil menurut Peraturan Presiden No. 36 Tahun 2005 dan Peraturan Kepala Badan Pertanahan Nasional Republik Indonesia No. 3 Tahun 2007 adalah instansi Pemerintah. Menurut Pasal 1 angka 1 Peraturan Kepala Badan Pertanahan Nasional Republik Indonesia No. 3 Tahun 2007, yang dimaksud instansi Pemerintah adalah Lembaga Negara, Departemen, Lembaga Pemerintah Non Departemen, Pemerintah Provinsi, atau Pemerintah Kabupaten/ Kota.

Ada 3 (tiga) cara perolehan tanah dalam pengadaan tanah berkala kecil menurut Peraturan Presiden No. 36 Tahun 2005 dan Peraturan Kepala Badan Pertanahan Nasional Republik Indonesia No. 3 Tahun 2007, adalah jual beli, atau tukar menukar, atau cara lain yang disepakati oleh kedua belah pihak.

Pengadaan tanah berskala kecil termasuk dalam pengadaan tanah untuk kepentingan umum. Oleh karena itu, bidang kegiatan pembangunan dalam pengadaan tanah berskala kecil adalah bidang kegiatan pembangunan sebagaimana diatur dalam Pasal 5 Peraturan Presiden No. 65 Tahun 2006, yaitu: (1) Jalan umum dan jalan tol, rela kereta api (di atas tanah, ruang atas tanah, ataupun di ruang bawah tanah), saluran air minum/ air bersih, saluran pembuangan air dan sanitasi; (2) waduk, bendungan, bendungan irigasi dan bangunan pengairan lainnya; (3) pelabuhan, Bandar udara, stasiun kereta api dan terminal; (4) fasilitas keselamatan umum, seperti tanggul penanggulangan bahaya banjir, lahar, dan lain-lain bencana; (5) tempat pembuangan sampah; (6) cagar alam dan cagar budaya; dan (6) pembangkit, transmisi, distribusi tenaga listrik.

Permasalahan yang hendak dikaji dalam tulisan ini dirumuskan sebagai berikut: A pakah cara jual beli, tukar menukar, atau cara lain yang disepakati oleh kedua belah pihak dapat ditempuh oleh instansi pemerintah dalam pengadaan tanah berskala kecil?

\section{Perolehan Tanah dalam Pengadaan Tanah Berskala Kecil}


Perdehan Tanah

Ada 3 (tiga) pilihan cara perolehan tanah dalam pengadaan tanah berskala kecil menurut Pasal 20 Peraturan Presiden No. 36 Tahun 2005 dan Pasal 54 Peraturan Kepala Badan Pertanahan Nasional Republik Indonesia No. 3 Tahun 2007, yaitu jual beli, atau tukar menukar, atau cara lain yang disepakati oleh kedua belah pihak. Penjelasan masing-masing cara perolehan tanah tersebut adalah:

\section{Jual beli}

Boedi Harsono menyatakan bahwa peralihan hak atas tanah dibagi menjadi 2 (dua) bentuk, yaitu: (1) Beralih, yang menunjuk pada pengertian berpindahnya hak atas tanah kepada pihak lain karena pemegangnya meninggal dunia (proses pewarisan). Dengan meninggalnya pemegang hak atas tanah, maka hak atas tanah berpindah kepada ahli warisnya; (2) Dialihkan, yang menunjuk pada pengertian berpindahnya hak atas tanah kepada pihak lain karena perbuatan hukum yang disengaja dilakukan dengan tujuan agar pihak lain tersebut memperoleh hak itu. Adapun perbuatan hukum tersebut dapat berupa jual beli, tukar menukar, hibah atau pemberian dengan wasiat. ${ }^{1}$

Obyek peralihan hak tidak hanya hak atas tanah. Namun, dalam perkembangannya, termasuk obyek peralihan hak adalah $\mathrm{Hak}$ Milik Atas Satuan Rumah Susun. Hal ini diatur dalam Undangundang No. 16 Tahun 1985 tentang Rumah Susun, Peraturan Pemerintah No. 4 Tahun 1988 tentang Rumah Susun, dan Peraturan Pemerintah No. 24Tahun 1997 tentang Pendaftaran Tanah.

Dari 2 (dua) bentuk peralihan hak atas tanah tersebut di atas menunjukkan bahwa jual beli merupakan peralihan hak atas tanah yang berbentuk dialihkan. Dalam jual beli hak terdapat perbuatan hukum yang sengaja dilakukan untuk memindahkan hak dari pemegang haknya sebagai penjual kepada pihak lain sebagai pembeli.

Istilah jual beli disebutkan dalam Pasal 26 UUPA, yaitu yang menyangkut jual beli hak milik atas tanah. dalam pasal-pasal lainnya tidak ada kata yang menyebutkan jual beli, tetapi disebutkan sebagai

1 Boedi Harsono, Undang-undang Pokok Agraria, Sedjarah Penjusunan Isi dan Pelaksanaannja, (Djakarta: Djambatan, 1971), hlm.12 
UripSantoso

dialihkan.2 Pengertian dialihkan menunjukkan suatu perbuatan hukum yang disengaja untuk memindahkan hak atas tanah kepada pihak lain melalui jual beli, tukar menukar, dan hibah wasiat. [2] Istilah jual beli disebutkan dalam Undang-undang No. 5 Tahun 1960 tentang Peraturan Dasar Pokok-pokok Agraria, atau disebut Undangundang Pokok Agraria (UUPA), Peraturan Pemerintah No. 40 Tahun 1996 tentang Hak Guna Usaha, Hak Guna Bangunan, dan Hak Pakai Atas Tanah, Peraturan Pemerintah No. 24 Tahun 1997, Peraturan Presiden No. 36 Tahun 2005. Dalam peraturan perundang-undangan tersebut hanya menyebut jual beli, namun tidak memberikan pengertian apa yang dimaksud jual beli.

Pengertian jual beli dikemukakan oleh Boedi Harsono, yaitu perbuatan hukum yang berupa penyerahan Hak Milik (penyerahan tanah untuk selama-lamanya) oleh penjual kepada pembeli, yang pada saat itu juga pembeli menyerahkan harganya kepada penjual. ${ }^{3}$ Jual beli tidak sebatas pada Hak Milik, namun dalam peraturan perundang-undangan disebutkan bahwa obyek jual beli adalah Hak Guna Usaha, Hak Guna Bangunan, Hak Pakai, dan Hak Milik Atas Satuan Rumah Susun. Jual beli hak atas tanah atau Hak Milik Atas Satuan Rumah Susun adalah suatu perbuatan hukum untuk menyerahkan hak atas tanah atau Hak Milik Atas Satuan Rumah Susun untuk selama-lamanya dari pemegang haknya sebagai penjual kepada pihak lain sebagai pembeli, dan secara bersamaan pihak pembeli menyerahkan sejumlah uang yang disepakati oleh kedua belah pihak sebagai harga kepada penjual.

Syarat sahnya pendaftaran jual beli hak atas tanah atau Hak Milik Atas Satuan Rumah Susun ada 2 (dua) macam, yaitu: Pertama, Syarat materiil. Pemegang hak atas tanah atau pemilik satuan rumah sebagai penjual berhak dan berwenang menjual hak atas tanah atau Hak Milik Atas Satuan Rumah Susun, sedangkan pembeli harus memenuhi syarat sebagai subyek hak atas tanah atau Hak Milik Atas Satuan Rumah Susun yang menjadi obyek jual beli.

2 Adrian Sutedi, Peralihan Hak A tas Tanah dan Pendaftarannya, (Jakarta: Sinar Grafika, 2007), hlm. 76.

3 Harsono, U ndang-undang P okok A graria, hlm. 135. 
Perdehan Tanah

Orang yang berhak menjual hak atas tanah atau Hak Milik Atas Satuan Rumah Susun adalah orang yang namanya yang tercantum dalam tanda bukti hak atas tanah atau Hak Milik Atas Satuan Rumah Susun. Orang lain tidak dapat menjual hak atas tanah atau Hak Milik Atas Satuan Rumah Susun, kecuali diberi kuasa menjual oleh pemegang hak atas tanah atau pemilik satuan rumah susun.

Orang yang berwenang menjual hak atas tanah atau Hak Milik Atas Satuan Rumah Susun adalah orang yang memenuhi kecakapan bertindak atau syarat dewasa untuk melakukan suatu perbuatan hukum. Kalau hak atas tanah atau Hak Milik A tas Satuan Rumah Susun yang akan dijual tersebut merupakan harta bersama, maka yang berwenang menjualnya adalah orang yang namanya tercantum dalam tanda bukti hak dengan persetujuan terlebih dahulu dari istri atau suaminya. Kalau penjualnya belum dewasa, maka yang berwenang menjual hak atas tanah atau Hak Milik Atas Satuan Rumah Susun tersebut adalah walinya.

Syarat materiil bagi pembeli, yaitu pembeli harus memenuhi syarat sebagai subyek hak atas tanah atau Hak Milik Atas Satuan Rumah Susun yang menjadi obyek jual beli. Kalau obyek jual beli itu berupa tanah Hak Milik atau Hak Milik Atas Satuan Rumah Susun yang berdiri di atas tanah Hak Milik, maka pihak yang dapat membeli adalah seseorang atau badan hukum yang memenuhi syarat sebagai subyek Hak Milik. Demikian pula, kalau obyek jual belinya Hak Guna Usaha, Hak Guna Bangunan, dan Hak Pakai, maka yang dapat membeli adalah orang atau badan hukum yang memenuhi syarat sebagai subyek Hak Guna Usaha, Hak Guna Bangunan, dan Hak Pakai.

Kedua, syarat formal. Dalam rangka pendaftaran pemindahan hak, maka jual beli hak atas tanah atau Hak Milik Atas Satuan Rumah Susun harus dibuktikan dengan akta yang dibuat oleh dan dihadapan Pejabat Pembuat Akta Tanah (PPAT). Syarat jual beli harus dibuktikan dengan akta PPAT diatur dalam Pasal; 37 ayat (1) Peraturan Pemerintah No. 24 Tahun 1997, yaitu "Peralihan hak atas tanah atau Hak Milik Atas Satuan Rumah Susun melalui jual beli (garis bawah penulis), tukar menukar, hibah, pemasukan dalam perusahaan dan perbuatan pemindahan hak lainnya, kecuali 
UripSantoso

pemindahan hak melalui lelang hanya dapat didaftarkan jika dibuktikan dengan akta yang dibuat oleh PPAT yang berwenang menurut ketentuan peraturan perundang-undangan yang berlaku".

Dengan telah dibuatnya akta jual beli oleh PPAT, maka pada saat itu telah terjadi pemindahan hak atas tanah atau Hak Milik A tas Satuan Rumah Susun dari pemegang haknya sebagai penjual kepada pihak lain sebagai pembeli. Namun, pemindahan hak ini hanya diketahui oleh kedua belah pihak (penjual dan pembeli), pihak ketiga tidak mengetahui adanya jual beli tersebut. Agar pihak ketiga mengetahuinya, maka jual beli hak atas tanah atau Hak Milik Atas Satuan Rumah Susun tersebut harus didaftarkan ke Kantor Pertanahan Kabupaten/ Kota setempat. Pendaftaran pemindahan hak tersebut merupakan alat pembuktian yang kuat dan dimaksudkan untuk dilakukan perubahan nama pemegang hak atas tanah atau pemilik satuan rumah susun yang tercantum dalam sertipikat dari pemegang hak yang lama sebagai penjual menjadi pemegang hak yang baru sebagai pembeli oleh Kepala Kantor Pertanahan Kabupaten/ Kota setempat serta dicatat dalam Buku Tanah.

\section{Tukar Menukar.}

Seperti halnya dengan jual beli, tukar menukar hak atas tanah atau Hak Milik A tas Satuan Rumah Susun merupakan peralihan hak yang berbentuk dialihkan, yaitu saling berpindahnya hak atas tanah atau Hak Milik Atas Satuan Rumah Susun dari pemegang haknya kepada pihak lain.

Istilah tukar menukar disebutkan dalam UUPA, Peraturan Pemerintah No. 40 Tahun 1996, Peraturan Pemerintah No. 24 Tahun 1997, Peraturan Presiden No. 36 Tahun 2005. Dalam peraturan perundang-undangan tersebut hanya menyebut tukar menukar, namun tidak memberikan pengertian apa yang dimaksud tukar menukar.

Boedi Harsono menyatakan bahwa Hak Milik atas tanah dapat juga beralih karena tanahnya ditukar dengan tanah yang lain. ${ }^{4}$ Bedanya dengan peralihan hak karena jual beli adalah bahwa dalam

\footnotetext{
${ }^{4}$ Ibid., hlm. 121.
} 
Perdehan Tanah

hal tukar menukar pemilik memperoleh benda lain sebagai ganti daripada tanah Hak Milik yang diserahkan. Tukar menukar tidak sebatas pada Hak Milik, namun dalam peraturan perundangundangan disebutkan bahwa obyek tukar menukar adalah Hak Guna Usaha, Hak Guna Bangunan, Hak Pakai, dan Hak Milik Atas Satuan Rumah Susun.

Tukar menukar bukan diartikan sebagai suatu perjanjian dalam mana seorang pemilik tanah berjanji akan menyerahkannya kepada pihak lain, tetapi merupakan perbuatan hukum yang berupa peralihan Hak Milik atas tanah yang bersangkutan kepada pihak yang menukarnya. Sebab itu tidak diatur dalam hukum perjanjian, tetapi dalam hukum tanah. ${ }^{5}$

Tukar menukar hak atas tanah atau Hak Milik Atas Satuan Rumah Susun adalah suatu perbuatan hukum berupa saling menyerahkan hak atas tanah atau Hak Milik Atas Satuan Rumah Susun untuk selama-lamanya dari pemegang hak yang satu kepada pemegang hak yang lain. Dalam tukar menukar hak ini, kedua belah pihak sebagai pemegang hak saling menukarkan hak atas tanah atau Hak Milik A tas Satuan Rumah Susunnya.

Ada 2 (dua) syarat sahnya pendaftaran pemindahan hak atas tanah atau Hak Milik Atas Satuan Rumah Susun melalui tukar menukar, yaitu: Pertama, syarat materiil. Para pemegang hak atas tanah atau pemilik satuan rumah berhak dan berwenang menukarkan hak atas tanah atau Hak Milik A tas Satuan Rumah Susun, sedangkan para pemegang hak atas tanah atau pemilik satuan rumah susun harus memenuhi syarat sebagai subyek hak atas tanah atau Hak Milik A tas Satuan Rumah Susun yang menjadi obyek tukar menukar.

Orang yang berhak menukarkan hak atas tanah atau Hak Milik Atas Satuan Rumah Susun adalah orang yang namanya yang tercantum dalam tanda bukti hak atas tanah atau Hak Milik Atas Satuan Rumah Susun. Orang lain tidak dapat menukarkan hak atas tanah atau Hak Milik A tas Satuan Rumah Susun, kecuali diberi kuasa menukarkan oleh pemegang hak atas tanah atau pemilik satuan rumah susun.

5 Effendi Perangin, Hukum Agraria Suatu Telaah D ari Sudut Pandang Praktisi H ukum, (Jakarta, Rajawali, 1989), hlm. 33 
UripSantoso

Orang yang berwenang menukarkan hak atas tanah atau Hak Milik Atas Satuan Rumah Susun adalah orang yang memenuhi kecakapan bertindak atau syarat dewasa untuk melakukan suatu perbuatan hukum. Kalau hak atas tanah atau Hak Milik A tas Satuan Rumah Susun yang akan dipertukarkan tersebut merupakan harta bersama, maka yang berwenang menukarkan adalah orang yang namanya tercantum dalam tanda bukti hak dengan persetujuan terlebih dahulu dari istri atau suaminya. Kalau pihak yang menukarkan belum dewasa, maka yang berwenang menukarkan hak atas tanah atau Hak Milik A tas Satuan Rumah Susun tersebut adalah walinya.

Syarat materiil bagi para pihak, yaitu kedua belah pihak harus memenuhi syarat sebagai subyek hak atas tanah atau Hak Milik Atas Satuan Rumah Susun yang menjadi obyek tukar menukar. Kalau tukar menukar itu berupa tanah Hak Milik atau Hak Milik Atas Satuan Rumah Susun yang berdiri di atas tanah Hak Milik, maka pihak yang dapat menukarkan adalah seseorang atau badan hukum yang memenuhi syarat sebagai subyek Hak Milik. Demikian pula, kalau obyek tukar menukarnya Hak Guna Usaha, Hak Guna Bangunan, dan Hak Pakai, maka yang dapat menukarkan adalah orang atau badan hukum yang memenuhi syarat sebagai subyek $\mathrm{Hak}$ Guna Usaha, Hak Guna Bangunan, dan Hak Pakai.

Kedua, syarat formal. Dalam rangka pendaftaran pemindahan hak, maka tukar menukar hak atas tanah atau Hak Milik Atas Satuan Rumah Susun harus dibuktikan dengan akta yang dibuat oleh dan dihadapan Pejabat Pembuat A kta Tanah (PPAT).

Syarat tukar menukar harus dibuktikan dengan akta PPAT diatur dalam Pasal; 37 ayat (1) Peraturan Pemerintah No. 24 Tahun 1997, yaitu "Peralihan hak atas tanah taua Hak Milik Atas Satuan Rumah Susun melalui jual beli, tukar menukar (garis bawah dari penulis), hibah, pemasukan dalam perusahaan dan perbuatan pemindahan hak lainnya, kecuali pemindahan hak melalui lelang hanya dapat didaftarkan jika dibuktikan dengan akta yang dibuat oleh PPAT yang berwenang menurut ketentuan peraturan perundang-undangan yang berlaku".

Dengan telah dibuatnya akta tukar menukar oleh PPAT, maka pada saat itu telah terjadi pemindahan hak atas tanah atau Hak Milik 
Perdehan Tanah

A tas Satuan Rumah Susun dari pemegang haknya kepada pihak lain. Namun, pemindahan hak ini hanya diketahui oleh kedua belah pihak, pihak ketiga tidak mengetahui adanya tukar menukar tersebut. Agar pihak ketiga mengetahuinya, maka tukar menukar hak atas tanah atau Hak Milik A tas Satuan Rumah Susun tersebut harus didaftarkan ke Kantor Pertanahan Kabupaten/Kota setempat. Pendaftaran pemindahan hak tersebut merupakan alat pembuktian yang kuat dan dimaksudkan untuk dilakukan perubahan nama pemegang hak atas tanah atau pemilik satuan rumah susun yang tercantum dalam sertipikat dari pemegang hak yang lama menjadi pemegang hak yang baru oleh Kepala Kantor Pertanahan Kabupaten/ Kota setempat serta dicatat dalam Buku Tanah.

\section{Cara lain yang Disepakati oleh Kedua Belah Pihak.}

Bentuk perolehan hak atas tanah dalam pengadaan tanah berskala kecil melalui cara lain yang disepakati oleh kedua belah pihak adalah pelepasan atau penyerahan hak atas tanah oleh pemegang haknya. Dalam peraturan perundang-undangan ditegaskan bahwa pelepasan atau penyerahan hak atas tanah merupakan salah satu faktor hapusnya hak atas tanah. Hapusnya hak atas tanah diatur dalam UUPA dan Peraturan Pemerintah No. 40 Tahun 1996.

Menurut Pasal 1 angka 6 Peraturan Presiden No. 36 Tahun 2005 jo Pasal 1 angka 3 Keputusan Menteri Negara Agraria/ Kepala Badan Pertanahan Nasional No. 21 Tahun 1994 tentang Tata Cara Perolehan Tanah Bagi Perusahaan Dalam Rangka Penanaman Modal, yang dimaksud pelepasan atau penyerahan hak atas tanah adalah kegiatan melepaskan hubungan hukum antara pemegang hak atas tanah dengan tanah yang dikuasainya dengan pemberian ganti kerugian atas dasar musyawarah. Dengan pelepasan atau penyerahan hak atas tanah, maka terputus sudah hubungan hukum antara pemegang hak atas tanah dengan tanah yang dikuasainya. Terputusnya hubungan hukum antara pemegang hak atas tanah dengan hak atas tanah yang dikuasainya tersebut terjadi dengan pemberian ganti kerugian yang bentuk dan besarnya ditetapkan dalam musyawarah antara pihak yang memerlukan tanah dengan pemegang hak atas tanah. 
UripSantoso

Pelepasan atau penyerahan hak atas tanah didahului oleh musyawarah antara pihak yang memerlukan tanah dengan pemegang hak atas tanah mengenai bentuk dan besarnya ganti kerugian. Kalau sudah tercapai kesepakatan dalam musyawarah mengenai bentuk dan besarnya ganti kerugian, maka dibuatlah akta pelepasan atau penyerahan hak atas tanah oleh notaries, atau surat pernyataaan pelepasan atau penyerahan hak atas tanah oleh pemegang hak atas tanah. seiring dengan penandatanganan akta pelepasan atau penyerahan hak atas tanah, surat pernyataan pelepasan atau penyerahan hak atas tanah, maka pihak yang memerlukan tanah menyerahkan ganti kerugian secara langsung kepada pemegang hak atas tanah.

Menurut Arie Sukanti Hutagalung, acara pelepasan hak ini ditempuh jika pihak yang bermaksud memperoleh dan menguasai tanah yang berstatus Hak Milik atau Eks Hak Milik Adat, namun tidak memenuhi syarat sebagai subyek pemegang hak atas tanah tersebut melalui pemindahan/ peralihan hak secara langsung. ${ }^{6}$ Pelepasan atau penyerahan hak atas tanah oleh pemegang haknya ditempuh oleh pihak yang memerlukan tanah disebabkan pihak yang memerlukan tanah tidak dapat memperoleh tanah yang berstatus Hak Milik melalui cara jual beli. Pihak yang memerlukan tanah tidak memenuhi syarat sebagai subyek Hak Milik, sehingga untuk memperoleh tanah yang berstatus Hak Milik ditempuh melalui cara pelepasan atau penyerahan hak atas tanah oleh pemegang haknya dengan pemberian ganti kerugian.

Boedi Harsono menyatakan bahwa dengan pelepasan hak atas tanah tidak berarti bahwa hak atas tanah berpindah dari pemegang hak atas tanah kepada pihak lain yang memberikan ganti kerugian, melainkan hak atas tanah tersebut hapus dan kembali menjadi tanah Negara atau tanah yang dikuasai langsung oleh Negara. Pelepasan hak atas tanah merupakan salah satu faktor penyebab hapusnya hak atas tanah dan bukan pemindahan hak atas tanah. ${ }^{7}$ Dengan pelepasan hak atas tanah oleh pemegang haknya, hak atas tanah tidak

\footnotetext{
${ }^{6}$ A rie Sukanti Hutagalung, Tebaran Pemikiran Seputar M asalah H ukum Tanah, (Jakarta: Lembaga Pemberdayaan Hukum Indonesia, 2005), hlm. 178.

7 Boedi Harsono, "Aspek Yuridis Penyediaan Tanah", Majalah Hukum dan Pembangunan, Nomor 2 tahun XX, (A pril, 1990), hlm. 168.
} 
Perdehan Tanah

berpindah kepada pihak yang memberikan ganti kerugian (pihak yang memerlukan tanah), melainkan memutuskan hubungan hukum antara pemegang hak atas tanah dengan hak atas tanah yang dikuasainya dan berakibat hak atas tanah menjadi hapus serta tanahnya kembali menjadi tanah Negara atau tanah yang dikuasai langsung oleh N egara.

Setelah dibuatkan akta pelepasan atau penyerahan hak atas tanah, atau surat pernyataan pelepasan atau penyerahan hak atas tanah, pihak yang memberikan ganti kerugian (pihak yang memerlukan tanah) mengajukan permohonan pemberian hak atas tanah Negara atas tanah yang dilepaskan atau diserahkan kepada Kepala Badan Pertanahan Nasional Republik Indonesia melalui Kepala Kantor Pertanahan Kabupaten/ Kota setempat. Kalau semua persyaratan yang ditentukan dalam permohonan pemberian hak atas tanah Negara dipenuhi oleh pemohon (pihak yang memerlukan tanah), maka oleh Kepala Badan Pertanahan Nasional Republik Indonesia, atau pejabat Badan Pertanahan Nasional Republik Indonesia yang diberi pelimpahan kewenangan, yaitu Kepala Kantor Wilayah Badan Pertanahan Nasional Provinsi atau Kepala Kantor Pertanahan Kabupaten/ Kota setempat diterbitkan Surat Keputusan Pemberian Hak (SKPH). SKPH didaftarkan oleh pemohon pemberian hak atas tanah negara kepada Kepala Kantor Pertanahan Kabupaten/ Kota setempat untuk dicatat dalam Buku Tanah dan diterbitkan sertipikat hak atas tanah sesuai yang dimohon sebagai tanda bukti haknya.

\section{Analisis terhadap Cara Perolehan Tanah dalam Pengadaan Tanah Berskala Kecil}

Pihak yang memerlukan tanah dalam pengadaan tanah berskala kecil adalah instansi Pemerintah, yang meliputi Lembaga Negara, Departemen, Lembaga Pemerintah Non Departemen, Pemerintah Provinsi, Pemerintah Kabupaten/ Kota. Hak penguasaan atas tanah yang dapat dikuasai oleh instansi Pemerintah adalah $\mathrm{Hak}$ Pakai yang bersifat right to use tidak right op dispossal, atau Hak Pengelolaan.

Pada umumnya, hak atas tanah yang diperlukan oleh instansi Pemerintah dalam pengadaan tanah berskala kecil berasal dari tanah 
UripSantoso

Hak Milik, dan tidak menutup kemungkinan berasal dari tanah Hak Guna Bangunan atau tanah Hak Pakai. Asal hak atas tanah yang diperlukan oleh instansi Pemerintah menentukan cara perolehan tanah yang dapat ditempuh oleh instansi Pemerintah dalam pengadaan tanah berskala kecil.

Pasal 20 Peraturan Presiden No. 36 Tahun 2005 jo Pasal 54 Peraturan Kepala Badan Pertanahan Nasional No. 3 Tahun 2007 menetapkan 3 (tiga) cara perolehan tanah dalam pengadaan tanah berskala kecil, yaitu jual beli, tukar menukar, atau pelepasan hak atas tanah. masing-masing cara perolehan tanah akan dianalisis sebagai berikut: Pertama, Jual beli. Kalau cara perolehan tanah dalam pengadaan tanah berskala kecil ditempuh melalui jual beli, maka instansi Pemerintah yang memerlukan tanah berkedudukan sebagai pihak pembeli, sedangkan pihak yang tanahnya diperlukan oleh instansi Pemerintah berkedudukan sebagai penjual. Kalau jual beli tersebut ditempuh sebagai cara perolehan tanah dalam pengadaan tanah berskala kecil oleh instansi Pemerintah, maka akan terjadi pemindahan hak atas tanah dari pemegang hak atas tanah sebagai penjual kepada instansi Pemerintah yang memerlukan tanah sebagai pembeli.

Instansi Pemerintah yang memerlukan tanah sebagai pembeli merupakan subyek Hak Pakai yang bersifat right to use tidak right of dispossal atau Hak Pengelolaan, sedangkan pihak penjual pada umumnya merupakan subyek Hak Milik.

Syarat sah materiil dalam pemindahan hak atas tanah melalui jual beli, adalah pihak pemegang hak atas tanah sebagai penjuak berhak dan berwenang menjual hak atas tanahnya, sedangkan pihak pembeli harus memenuhi syarat sebagai subyek hak atas tanah yang menjadi obyek jual beli hak atas tanah. Dari segi syarat materiil dalam jual beli hak atas tanah ini, instansi Pemerintah yang memerlukan tanah yang berkedudukan sebagai pembeli tidak memenuhi syarat materiil sebagai subyek hak dari hak atas tanah yang akan dibelinya. Kalau hak atas tanah yang menjadi obyek jual beli adalah Hak Milik, maka jual beli hak atas tanah tidak dapat dilaksanakan disebabkan menemui hambatan yuridis yaitu instansi Pemerintah yang memerlukan tanah bukan atau tidak memenuhi syarat sebagai subyek Hak Milik. 
A pabila jual beli hak atas tanah antara instansi Pemerintah yang memerlukan tanah sebagai pembeli dan pemilik tanah sebagai penjual tetap dilakukan, maka berdasarkan ketentuan Pasal 26 ayat (2) UUPA jual beli Hak Milik atas tanah batal demi hukum dan berakibat hak atas tanah yang diperjualbelikan menjadi hapus dan tanahnya kembali menjadi tanah yang dikuasai langsung oleh negara.

Dari segi syarat formal dalam pendaftaran pemindahan hak atas tanah melalui jual beli sebagaimana ditegaskan dalam Pasal 37 ayat (1) Peraturan Pemerintah No. 24 Tahun 1997 harus dibuktikan dengan akta yang dibuat oleh dan dihadapan PPAT yang berwenang. Dari segi syarat formal ini, PPAT berwenang untuk tidak membuatkan akta jual beli disebabkan instansi Pemerintah yang memerlukan tanah sebagai pembeli tidak memenuhi syarat sebagai subyek Hak Milik yang menjadi obyek jual beli tanah. Kewenangan untuk menolak membuatkan akta jual beli oleh PPAT ditegaskan dalam Pasal 39 ayat (1) huruf c Peraturan Pemerintah No. 24 Tahun 1997. Oleh karena jual beli hak atas tanah tidak dibuktikan dengan akta PPAT, maka permohonan pendaftaran pemindahan hak atas tanahnya ditolak oleh Kepala Kantor Pertanahan Kabupaten/ Kota setempat.

Dengan demikian, cara perolehan tanah dalam pengadaan tanah berskala kecil oleh instansi Pemerintah yang memerlukan tanah melalui jual beli tidak dapat dilaksanakan disebabkan menemui hambatan yuridis, yaitu tidak terpenuhinya syarat materiil dan syarat formal dalam jual beli hak atas tanah.

Kedua, tukar menukar. Kalau pengadaan tanah berskala kecil, perolehan tanahnya ditempuh melalui tukar menukar, maka instansi Pemerintah yang memerlukan tanah dan pemegang hak atas tanah saling menukar hak atas tanahnya. Kalau tukar menukar dalam pengadaan tanah berskala kecil oleh instansi Pemerintah, maka akan terjadi pemindahan hak atas tanah dari pemegang hak atas tanah kepada instansi Pemerintah yang memerlukan tanah dan sebaliknya hak atas tanah yang dikuasai oleh instansi Pemerintah yang memerlukan tanah berpindah kepada pemegang hak atas tanah.

Instansi Pemerintah yang memerlukan tanah sebagai pembeli merupakan subyek Hak Pakai yang bersifat right to use tidak right of disposal, atau Hak Pengelolaan, sedangkan pihak pemegang hak atas 
UripSantoso

tanah yang tanahnya diperlukan oleh instansi Pemerintah pada umumnya merupakan subyek Hak Milik.

Dalam tukar menukar hak atas tanah, para pihaknya haruslah sama-sama memenuhi syarat sebagai subyek hak dari hak atas tanah yang menjadi obyek tukar menukar hak atas tanah, misalnya kalau hak atas tanah yang menjadi obyek tukar menukarnya adalah Hak Milik, maka para pihaknya haruslah memenuhi syarat sebagai subyek Hak Milik.

Syarat sah materiil dalam pendaftaran pemindahan hak atas tanah melalui tukar menukar adalah kedua belah pihak harus memenuhi syarat sebagai subyek hak atas tanah yang menjadi obyek tukar menukar hak atas tanah. Dari segi syarat materiil dalam tukar menukar hak atas tanah, instansi Pemerintah yang memerlukan tanah yang berkedudukan sebagai pihak yang memerlukan tanah tidak memenuhi syarat mareriil sebagai subyek hak atas tanah yang ditukarnya. Kalau hak atas tanah yang diperlukan oleh instansi Pemerintah berstatus Hak Milik, maka tukar menukar hak atas tanah tidak dapat dilaksanakan disebabkan menemui hambatan yuridis yaitu instansi Pemerintah yang memerlukan tanah bukan atau tidak memenuhi syarat sebagai subyek Hak Milik.

Apabila tukar menukar hak atas tanah antara instansi Pemerintah sebagai pihak yang memerlukan tanah dan pemegang hak atas tanah sebagai pihak yang diperlukan tetap dilakukan, maka berdasarkan ketentuan Pasal 26 ayat (2) UUPA, tukar menukar Hak Milik atas tanah batal demi hukum dan berakibat hak atas tanah yang dipertukarkan menjadi hapus dan tanahnya kembali menjadi tanah yang dikuasai langsung oleh Negara.

Dari segi syarat formal dalam pendaftaran pemindahan hak atas tanah melalui tukar menukar sebagaimana ditegaskan dalam Pasal 37 ayat (1) Peraturan Pemerintah No. 24 Tahun 1997 harus dibuktikan dengan akta yang dibuat oleh dan dihadapan PPAT yang berwenang. Dari segi syarat formal ini, PPAT berwenang untuk tidak membuatkan akta tukar menukar disebabkan instansi Pemerintah sebagai pihak yang memerlukan tanah tidak memenuhi syarat sebagai subyek Hak Milik yang menjadi obyek tukar menukar tanah. Kewenangan untuk menolak membuatkan akta tukar menukar oleh PPAT ditegaskan dalam Pasal 39 ayat (1) huruf c Peraturan 
Perdehan Tanah

Pemerintah No. 24 Tahun 1997. Oleh karena tukar menukar atas tanah tidak dibuktikan dengan akta PPAT, maka permohonan pendaftaran pemindahan hak atas tanahnya ditolak oleh Kepala Kantor Pertanahan Kabupaten/ Kota setempat.

Dengan demikian, cara perolehan tanah dalam pengadaan tanah berskala kecil oleh instansi Pemerintah yang memerlukan tanah melalui tukar menukar tidak dapat dilaksanakan disebabkan menemui hambatan yuridis, yaitu tidak terpenuhinya syarat materiil dan syarat formal dalam tukar menukar hak atas tanah.

Ketiga, pelepasan hak atas tanah. Kalau perolehan tanah dalam pengadaan tanah berskala kecil ditempuh melalui cara pelepasan atau penyerahan hak atas tanah, maka instansi Pemerintah yang memerlukan tanah berkedudukan sebagai pihak yang menerima pelepasan atau penyerahan hak atas tanah, sedangkan pemegang hak atas tanah berkedudukan sebagai pihak yang melepaskan atau menyerahkan hak atas tanah.

Pelepasan atau penyerahan hak atas tanah dapat dilakukan apabila telah mencapai kesepakatan dalam musyawarah antara instansi Pemerintah yang memerlukan tanah dan pemegang hak atas tanah mengenai bentuk dan besarnya ganti kerugian. Kalau sudah mencapai kesepakatan dalam musyawarah mengenai bentuk dan besarnya ganti kerugian, maka dibuatlah akta pelepasan atau penyerahan hak atas tanah oleh notaris, atau surat pernyataan pelepasan atau penyerahan hak atas tanah oleh pemegang haknya.

Yang menentukan dalam pelepasan atau penyerahan hak atas tanah adalah tercapainya kesepakatan dalam musyawarah mengenai bentuk dan besarnya ganti kerugian antara instansi Pemerintah yang memerlukan tanah dengan pemegang hak atas tanah, dan pihak yang melepaskan atau menyerahkan hak atas tanah adalah orang yang berhak dan berwenang melepaskan atau menyerahkan hak atas tanahnya. Dalam pelaksanaan pelepasan atau penyerahan hak atas tanah tidak ada syarat materiil bagi instansi Pemerintah yang memerlukan tanah, yaitu tidak ada syarat instansi Pemerintah yang memerlukan tanah harus memenuhi syarat sebagai subyek hak dari hak atas tanah yang dilepaskan atau diserahkan. Dalam pelepasan atau penyerahan hak atas tanah tidak terpengaruh asal status hak atas 
UripSantoso

tanah yang diperlukan oleh instansi Pemerintah, apakah Hak Milik, atau Hak Guna Bangunan.

Dengan demikian, cara perolehan tanah dalam pengadaan tanah berskala kecil oleh instansi Pemerintah yang memerlukan tanah melalui pelepasan atau penyerahan hak atas tanah oleh pemegang haknya dapat dilaksanakan disebabkan tidak adanya hambatan yuridis dalam perolehan tanahnya.

\section{Penutup}

Dari 3 (tiga) cara perolehan tanah dalam pengadaan tanah berskala kecil menurut Peraturan Presiden No. 36 Tahun 2005 jo Peraturan Kepala Badan Pertanahan Nasional Republik Indonesia No. 3 Tahun 2007, cara perolehan tanah melalui jual beli dan tukar menukar tidak dapat dilakukan oleh instansi Pemerintah yang memerlukan tanah disebabkan instansi Pemerintah yang memerlukan tanah tidak memenuhi syarat materiil dalam pelaksanaan jual beli atau tukar menukar tanah. Di dalam cara perolehan tanah melalui jual beli dan tukar-menukar, instansi Pemerintah yang memerlukan tanah yang berkedudukan sebagai pihak yang memerlukan tanah tidak memenuhi syarat mareriil sebagai subyek hak atas tanah yang akan dibeli atau ditukarnya.

Cara perolehan tanah yang dapat dilakukan oleh instansi Pemerintah dalam pengadaan tanah berskala kecil adalah melalui pelepasan atau penyerahan hak atas tanah oleh pemegang haknya dengan pemberian ganti kerugian. Pelepasan hak atas tanah tersebut dapat dilakukan apabila telah mencapai kesepakatan dalam musyawarah, yang mencakup bentuk dan besarnya ganti kerugian, antara instansi Pemerintah yang memerlukan tanah dan pemegang hak atas tanah mengenai bentuk dan besarnya ganti kerugian, yang selanjutnya dibuatlah akta pelepasan atau penyerahan hak atas tanah oleh notaris, atau surat pernyataan pelepasan atau penyerahan hak atas tanah oleh pemegang haknya.

\section{D aftar Pustaka}

Harsono, Boedi. U ndang-undang Pokok Agraria, Sedjarah Penjusunan Isi dan Pelaksanaannja. Djambatan: Djakarta, 1971. 
Perdehan Tanah

Hutagalung, Arie Sukanti. Tebaran Pemikiran Seputar M asalah Hukum Tanah. Jakarta: Lembaga Pemberdayaan Hukum Indonesia, 2005.

Perangin, Effendi. Hukum Agraria Suatu Telaah Dari Sudut Pandang Praktisi H ukum. Jakarta: Rajawali, 1989.

Sutedi, Adrian. Peralihan Hak A tas Tanah dan Pendaftarannya. Jakarta: Sinar Grafika, 2007.

Undang-undang No. 5 Tahun 1960 tentang Peraturan Dasar Pokokpokok A graria.

Undang-undang No. 16 Tahun 1985 tentang Rumah Susun.

Peraturan Pemerintah N o. 4 Tahun 1988 tentang Rumah Susun.

Peraturan Pemerintah No. 40 Tahun 1996 tentang Hak Guna U saha, $\mathrm{H}$ ak Guna Bangunan, dan Hak Pakai A tas Tanah.

Peraturan Pemerintah N o. 24 Tahun 1997 tentang P endaftaran Tanah.

Peraturan Presiden No. 36 Tahun 2005 tentang Pengadaan Tanah Bagi Pelaksanaan Pembangunan U ntuk Kepentingan U mum.

Peraturan Presiden No. 65 Tahun 2006 tentang Perubahan A tas Peraturan Presiden Nomor 36 Tahun 2005 tentang Pengadaan Tanah Bagi Pelaksanaan Pembangunan U ntuk Kepentingan U mum.

Keputusan Presiden No. 55 Tahun 1993 tentang Pengadaan Tanah Bagi Pelaksanaan Pembangunan U ntuk Kepentingan U mum.

Peraturan Menteri Negara Agraria/ Kepala Badan Pertanahan Nasional No. 1 Tahun 1994 tentang Ketentuan Pelaksanaan Keputusan Presiden N omor 55 Tahun 1993 tentang Pengadaan Tanah Bagi Pelaksanaan Pembangunan U ntuk Kepentingan U mum.

Peraturan Kepala Badan Pertanahan Nasional Republik Indonesia No. 3 Tahun 2007 tentang Ketentuan Pelaksanaan Peraturan Presiden N omor 36 Tahun 2005 tentang Pengadaan Tanah Bagi Pelaksanaan Pembangunan Untuk Kepentingan Umum Sebagaimana Telah Diubah dengan Peraturan Presiden Nomor 65 Tahun 2006 tentang Perubahan A tas Peraturan Presiden Nomor 36 Tahun 2005 tentang Pengadaan Tanah Bagi Pelaksanaan Pembangunan Untuk Kepentingan U mum. 
UripSantoso

Keputusan Menteri Negara Agraria/ Kepala Badan Pertanahan Nasional No. 21 Tahun 1994 tentang Tata Cara Perolehan Tanah Bagi Perusahaan D alam Rangka Penanaman M odal. 